\title{
Study on Constraints and Adoption of Black Gram Production Technology by the Farmers in Mirzapur District of Uttar Pradesh, India
}

\author{
Shani Kumar Singh*, Arun Kumar Singh and Kailash Jakhar \\ Department of Extension Education, Institute of Agricultural Sciences, Banaras Hindu \\ University, Varanasi, Uttar Pradesh, India \\ *Corresponding author
}

A B S T R A C T

\begin{tabular}{|l|}
\hline Ke y w o r d s \\
Black gram, \\
$\begin{array}{l}\text { Production, } \\
\text { Technology, } \\
\text { Cultivation, Adoption, } \\
\text { Constraints. }\end{array}$ \\
\hline Article Info \\
\hline $\begin{array}{l}\text { Accepted: } \\
\text { 04 September } 2017 \\
\text { Available Online: } \\
\text { 10 October } 2017\end{array}$ \\
\hline
\end{tabular}

Farmers had a medium level of adoption about improved practices of black gram cultivation in the Mirzapur district of Uttar Pradesh. Majority (82.5\%) of the respondent adopted the recommended varieties and $(73.33 \%)$ of the respondent had adopted the recommended control measures of disease and insect pest, while in case of recommended manure and fertilizer application, (79.16\%) of the respondent had adopted FYM application and $(66.66 \%)$ percent respondent had adopted the recommended chemical fertilizer application, and cultural practices cent percent of the respondent had adopted them. Majority of the respondent (95.93\%) constraints faced by complexity, it was also fallowed by lack of technical guidance (93.33\%), not existing of the market (92.5\%), lack of marketing facilities (91.66\%), non-availability of skilled labour $(90.83 \%)$, monopoly of merchant in the market (51.66\%), and lack of financial support (43.33\%) respectively.

\section{Introduction}

Pulses belong to one of the largest family Leguminosae. Black gram is mainly cultivated in Indian subcontinent. Black lentil is nothing but the split black gram and after removing black skin it is sold as white lentil. In India Black gram is popular as "Urad dal" and it is highly prized pulse among all the pulses. Apart from India it is also cultivated in Pakistan, Afghanistan, Bangladesh and Myanmar. Most suitable climate to cultivate Black gram is $27-30^{\circ} \mathrm{C}$ with heavy rainfall. This annual crop prefers loamy soil which has high water preservation capability. Black gram grows normally in 90120 days and it also enriches the soil with nitrogen. India is major producer and consumer country of black gram. Black gram best source of protein, fat and carbohydrates and also contains iron, folic acid, calcium, magnesium, potassium and vitamin $\mathrm{B}$ which are necessary for our body It has two types of fibers: soluble and insoluble. Insoluble fiber helps to prevent constipation and soluble fiber helps in our digestion system. It also helps to reduce cholesterol which ultimately improves cardiovascular health. High amount of magnesium and folate of black gram supports blood circulation. Black gram has medical properties which help to heal Rheumatic pains, stiff shoulder and contracted knees. In India, the area, production and productivity of Pulses were 
24.91 million hectares, 16.35 million tonnes and $733 \mathrm{~kg}$ per hectare, respectively during 2015-2016. The area under pulses has increased from 19 million ha. in 1950-51 to 24.91 million ha. in 2015-2016. However, the per capita daily availability of pulses has come down significantly from 51.1 gram per day in 1971 to about 42.00 gram in 20152016 as against WHO recommendation of 80 gram per day. Mainly due to stagnation in the production of pulses over the last three decades. In general, pulses give lower yield than cereals. This led to the assumption that pulses may have a lower genetic potential for yield than cereals. However, available evidence shows that grain legumes have as high or even higher genetic potential for yield as the cereal crops (DAC \& FW, 2015-16).

Black gram popularly known as Urd bean, Urid or mash is an important pulse crop in India. Black gram (Vigna mungo L) reported being originated in India. Its references have also been found in Vedic texts such as Kautilya's 'Arthasasthra' and in 'CharakSamhita' lends support to the presumption of its origin in India. India is the largest producer and consumer of a Black gram in the world. Black gram is a rich protein food. In Black gram contains 26.2 percent crude protein 1.2 percent Fat and 56.6 percent carbohydrate. The pods are long and cylindrical and about 4 to 6 centimeters in length four to ten seeds in a pod. The seeds are generally black or very dark brown. The crop is suitable for intercropping with different crops such as cotton, sorghum, pearl millet, green gram, maize, soybean, groundnut, for increasing production and maintaining soil fertility. It is extensively grown under varying climatic conditions and soil types in India. It is also cultivated in many tropical and sub-tropical countries of Asia, Africa and Central America, although, India, Pakistan, Bangladesh, Burma and Sri Lanka are the principal countries contributing to the world production. The black gram in
India is mainly grown in the states of Madhya Pradesh, Uttar Pradesh, Bihar, Punjab, Maharashtra, West Bengal and Tamil Nadu. Black gram is mostly grown as a rainfed crop during summers in Northern India and in winters in Peninsular and Southern India.

During 2015-16, Urd bean accounted for an area of 3.19 million hectare, production 1.95 million tones and average productivity $596 \mathrm{~kg}$ per hectare. The production of pulses, in general and black gram in particular, has not been able to keep pace with the rapid increase in demand by ever increasing population.

\section{Materials and Methods}

The present study was carried out in the Mirzapur district of Uttar Pradesh in year 2015-2016. A multistage sampling design was adopted to select sample for data collection. In total 120 farmers of the three villages of Mangraha, Sikhad, Ramgarh selected randomly after making a list of the villages having black gram cultivation. An interview schedule was prepared so as to collect the information in line with the objective of the study. Personal interview technique was used for data collection Based on the cumulative knowledge score obtained the respondents were categorized into three categories viz., low, medium and high. Percentile was used to find out the adoption level of the farmers.

\section{Results and Discussion}

\section{Overall adoption level of black gram grower about recommended cultivation practices}

The analysis of the data in table 1 revealed that majority of $(82.5 \%)$ of the respondent had medium level of adoption of the cultivation practices fallowed while majority $(9.17 \%)$ of the low and high $(8.33 \%)$ level adoption of recommended cultivation practices. 
Adoption of individual recommended cultivation practices of black gram growers

It is evident from table 2 that 82.5 percent of the respondent adopted the recommended varieties viz., Punt U-1, Azad-1, Pant U-35, and Tyape-1. Regarding soil and its preparation cent percent of the respondent adopted the recommended cultivation practices, and cent percent of the respondent adopted recommended planting material. In case of spacing 50.83 percent respondent adopted recommended spacing. Cent percent respondent had adopted the right time sowing. In case of recommended manure and fertilizer application, 79.16 percent of the respondent had adopted FYM application while 66.66 percent respondent had adopted the recommended chemical fertilizer application, and cultural practices cent percent of the respondent had adopted them.

80.84 percent respondents had adopted recommended water management practices. 55 percent and 73.33 percent of the respondent had adopted the recommended control measures of disease and insect pest. Regarding production of Urd cent percent of the respondent adopted the yield

Table.1 Overall adoption of Black gram grower about recommended cultivation practices

$(\mathrm{N}=120)$

\begin{tabular}{|c|l|c|c|}
\hline S. No. & \multicolumn{1}{|c|}{ Categories } & Frequency & Percentage \\
\hline 1 & Low & 11 & 9.17 \\
\hline 2 & Medium & 99 & 82.5 \\
\hline 3 & High & 10 & 8.33 \\
\hline
\end{tabular}

Table.2 Adoption of individual recommended cultivation practices of Black gram growers

\begin{tabular}{|c|l|c|c|}
\hline S. No. & \multicolumn{1}{|c|}{ Particular } & Frequency & Percentage \\
\hline 01. & Recommended varieties & 99 & 82.5 \\
\hline 02. & Soil and its preparation & 120 & 100 \\
\hline 03. & Planting material & 120 & 100 \\
\hline 04. & Spacing & 61 & 50.83 \\
\hline 05. & Sowing time & 120 & 100 \\
\hline 06. & FYM & 95 & 79.16 \\
\hline 07. & N.P.K. & 80 & 66.66 \\
\hline 08. & Cultural practices & 120 & 800.84 \\
\hline 09. & Water management & 97 & \\
\hline \multirow{2}{*}{0.} & Disease & & 55 \\
\cline { 2 - 4 } & Control measure as recommended & 66 & \\
\hline \multirow{2}{*}{11.} & Insect Pest & & 73 \\
\cline { 2 - 4 } & Control measure as recommended & 88 & \\
\hline
\end{tabular}

Table.3 Constraints faced by farmer

\begin{tabular}{|c|l|c|c|}
\hline S. No. & \multicolumn{1}{|c|}{ Constraints } & Frequency & Percentage \\
\hline $\mathbf{1}$ & Lack of technical guidance & 112 & 93.33 \\
\hline $\mathbf{2}$ & Complexity & 115 & 95.83 \\
\hline $\mathbf{3}$ & Lack of financial support & 52 & 43.33 \\
\hline $\mathbf{4}$ & Not existing of the potential market & 111 & 92.50 \\
\hline $\mathbf{5}$ & Monopoly of Merchant in the market & 62 & 51.66 \\
\hline $\mathbf{6}$ & Non-availability of skilled labour & 109 & 90.83 \\
\hline $\mathbf{7}$ & Lack of marketing facilities & 110 & 91.66 \\
\hline
\end{tabular}




\section{Constraints faced by farmer}

Table 3 revealed that majority of the respondent $(95.93 \%)$ constraints faced by complexity, it was also fallowed by lack of technical guidance $(93.33 \%)$, not existing of the market (92.5\%), lack of marketing facilities $(91.66 \%)$, non-availability of skilled labour $(90.83 \%)$, monopoly of merchant in the market $(51.66 \%)$ and lack of financial support (43.33\%).

Majority of $(82.5 \%)$ of the respondent had medium level of adoption of the cultivation practices fallowed while majority $(9.17 \%)$ of the low and high (8.33\%) level adoption of recommended cultivation practices. Majority $(82.5 \%)$ of the respondent adopted the recommended varieties. Soil and its preparation cent percent of the respondent adopted the recommended cultivation practices, and Cent percent of the respondent adopted recommended planting material. In case of spacing 50.83 percent respondent adopted recommended spacing. Cent percent respondent had adopted the right time sowing. In case of recommended manure and fertilizer application, 79.16 percent of the respondent had adopted FYM application while 66.66 percent respondent had adopted the recommended chemical fertilizer application, and cultural practices cent percent of the respondent had adopted them. 80.84 percent respondents had adopted recommended water management practices. 55 percent and 73.33 percent of the respondent had adopted the recommended control measures of disease and insect pest. Regarding production of Urd cent percent of the respondent adopted the yield. Majority of the respondent (95.93\%) constraints faced by complexity, it was also fallowed by lack of technical guidance $(93.33 \%)$, not existing of the market $(92.5 \%)$, lack of marketing facilities (91.66\%), nonavailability of skilled labour (90.83\%), monopoly of merchant in the market (51.66\%), lack of financial support (43.33\%) respectively.

\section{References}

Ahire, M.C., 2004. Constraint's in Adoption of recommended practices of betel vine and it Marketing. Ind. Res. J. of ext. $E d u, 4(3)$.

Amutha, D., 2011. Constraints and Techniques for Improving Pulses Production in Tamil Nadu, India. International Journal of Bioresource and Stress Management, 2(2), $159-162$.

Anonymous, 2015-16. Vital statistics. Department of agriculture, cooperation \& farmers' welfare ministry of agriculture \& farmers' welfare, GOI, New Delhi (INDIA).

Arun, S.K., 2001. A Study of the Technological Gap and The constraints in the Adoption of Rape Seed/Mustard Crop Technology among Farmers in Western Uttar Pradesh. Ph.D. Thesis (Unpub.) C.C.S. University Meerut.

Dhamodaran, T., and Vasanthakumar, J. 2001. Relationship between selected characteristics of registered sugarcane growers and their extent of adoption of improved sugarcane cultivation practices. J. Extn. Edu, 12(2), 31383143.

Dwivedi, A. P., Singh, S. R. K., Mishra, A., Singh, R. P., and Singh, M. 2011. Adoption of Improved Production Technology of Pigeonpea. Journal of Community Mobilization and Sustainable Development, 6(2), 150154.

Girase, K.A., and Kamble, L.P. 1991. Constraints in Adoption of fertilizers and plant Protection measures in Dryland Bajra Cultivation. Maha, J. Ext. Edu, 10 (1), 41-44.

Islam, M., Mohanty, A. K. and Kumar, S. 2016. Correlating Growth, Yield and Adoption of Urdbean Technologies. Indian Research Journal 
of Extension Education, 11(2), 20-24

Kadam, R. P., Umate, S. M., Pawar, G. S. and Lad, A. S. 2014. Constraint faced in adoption of recommended package practices of green gram. Agriculture Update, 9(4), 528-530.

Khare, A., Wakle, P. K., Shambharkar, Y. B. and Patil, J. 2013. Correlates of adoption and constraints faced by gram farmers in adoption of improved cultivation practices. Indian Journal of Research, 2(8-10).

Khuspe, S.B., and Kadam, R. P. 2012. Adoption gap in recommended production practices of chickpea. Agriculture Update, 7(3-4), 301-303.

Meena, N. R., Sisodia, S. S., Jain, H. K., Yadav, C. M., \& Khan, P. M. 2011. Adoption and Opinion of farmers towards of improved Cluster Bean cultivation practices among the farmers in Jaipur district of Rajasthan. Journal of Progressive Agriculture, 2(2), 31-34.

Meena, R.K., 2002. Adoption of improved cultivation practices of tomato by the farmers of Bassipanchayatsamiti of Jaipur district (Raj.) M.Sc (Ag.)
(UnPub) Thesis R.A.U Campus Jobner. Meena, S., 2015. Knowledge and Adoption of Farmers on Management of Pod Borer in Chickpea Crop under Rainfed Condition of Rajasthan. Indian Journal of Dryland Agricultural Research and Development, 30(1), 77-82.

NA, V. A., and Singh, G. 2013. Adoption of improved practices of pigeonpea.Journal of Food Legumes, 26(1-2), 93-95.

Sadangi, B., and Singh, R. P. 1994. Constraints in occupational diversification. Ind. Jour. of Extn. Edu, 30(1-4), 8-15.

Singh, I., Singh, K. K. and Gautam, U. S. 2012. Constraints in Adoption of Soybean Production Technology. Indian Research Journal of Extension Education, Special Issue (Volume II): 16 .

Tyagi, M. S., 1995. A Study of technological Gap and the constraints in the Adoption of oil Seed crops Technology among the farmers in Western U.P. Ph.D. (UnPub) Thesis C.C.S. University Meerut.

\section{How to cite this article:}

Shani Kumar Singh, Arun Kumar Singh and Kailash Jakhar. 2017. Study on Constraints and Adoption of Black Gram Production Technology by the Farmers in Mirzapur District of Uttar Pradesh, India. Int.J.Curr.Microbiol.App.Sci. 6(10): 174-178. doi: https://doi.org/10.20546/ijcmas.2017.610.022 